\title{
Venture capital needs for sustainable development of clean technologies
}

\section{Maria Tunberg*}

Swedish University of Agricultural Sciences,

Rådmansgatan 8 ,

Stockholm SE-114 25, Sweden

E-mail: maria.tunberg@gmail.com

*Corresponding author

\section{Cecilia Mark-Herbert}

Department of Economics,

Swedish University of Agricultural Sciences,

Box 7013,

Uppsala SE-750 07, Sweden

E-mail: cecilia.mark-herbert@slu.se

\section{Charles Neame}

The Glasgow School of Art,

167 Renfrew Street,

Glasgow G3 6RQ, UK

E-mail: c.neame@gsa.ac.uk

\begin{abstract}
Challenges of evaluating new evolving technologies are particularly pronounced for clean technology firms (CTFs) in need of venture capital (VC). This study investigates how Technology Approval Group (TAG) may bridge an identified funding gap. TAG is a communication tool enabling investors that traditionally would not invest that early in an innovation to feel confident in injecting VC into developing CTFs. In the study, challenges facing the investors include high levels of risk and small investment sums required. Additional characteristics that affect the funding process are the market size, the communication platforms and the political climate. A successful implementation of TAG in the water sector, in the UK, provided inspiration for expanding the use to other sectors and geographical markets where new challenges were identified. The identified risks with using a tool like TAG are associated with ethical questions, handling dependencies and the challenge of forecasting sustainable technological development.
\end{abstract}

Keywords: CT; clean technology; NTBFs; new technology-based firms; sustainable development; $\mathrm{VC}$; venture capital; funding gap.

Reference to this paper should be made as follows: Tunberg, M., Mark-Herbert, C. and Neame, C. (2011) 'Venture capital needs for sustainable development of clean technologies', Int. J. Sustainable Economy, Vol. 3, No. 4, pp.395-409.

Copyright (C) 2011 Inderscience Enterprises Ltd. 
Biographical notes: Maria Tunberg holds an MSc from Cranfield University, England, and a Swedish Master in Business Administration with focus on natural resource management from the Swedish University of Agricultural Sciences. She graduated in September 2006 and has since been working internationally (in Denmark, China and Spain) within the wind energy sector. Currently, she is employed by the Swedish government working with international renewable energy projects. Her research has been presented at two academic conferences, AGSE International Entrepreneurship Research Exchange at the University of Adelaide, South Australia (3-6 February, 2009) and Corporate Responsibility Research Conference at the University of Vaasa, Finland (7-9 September, 2009).

Cecilia Mark-Herbert is an Associate Professor in the Department of Economics at the Swedish University of Agricultural Sciences. She works as a Researcher and Lecturer in Marketing. Her research specialisation in sustainable marketing management is related to economic, environmental, social and ethical aspects of corporate conduct, e.g. R\&D management, healthand communication management, gender studies and organisational aspects of sustainable marketing management.

Charles Neame studied Agricultural Economics at Wye College, London University and specialised in Agricultural and Environmental Management at Cranfield University for 18 years. However, his Doctoral Research was in the field of Academic Development in Higher Education, and he now works as an Academic Developer at The Glasgow School of Art.

\section{Introduction}

The idea of turning environmental concerns into responsible corporate conduct and business opportunities is currently experiencing a rapid upswing. Investment activity is increasing in the clean technology (CT) market (Deloitte, 2006) and venture capital (VC) investors, see $\mathrm{CT}$ as the most promising investment sector for the coming years (Berggren and Dagh, 2008). The part of the environmental sector that is, of particular, interest for $\mathrm{VC}$ investments is, within the $\mathrm{VC}$ industry, labelled $\mathrm{CT}^{1}$, the definition adopted in this study.

Investigations show that lack of capital is the largest single obstacle for an expansion of the CT sector in Sweden (IVA, 2007) in spite of forecasted growth (Andreasson et al., 2008). Two main reasons are distinguished. Firstly, many investors consider CT as too risky for investment. Secondly, CT firm managers are often reluctant to take in external funding since this may lead to a decreased level of internal control.

A UK-based consultancy firm (Mouchel) recognised the problem and developed the technology approval group (TAG) as a remedy to the funding gap (TAG is since 2010 operated by Isle Utilities). The group consists of representatives of the end-users of the technology who give their expert opinion on the future potential of a particular clean technology firm's (CTF) product or service.

During 2006, the process of introducing TAG in the Swedish market was initiated, but the concept was not taken up as quickly as in the UK. This 'lag' may result from a set of specific features of the Swedish CT market and within this context the aim and objectives of this study have been developed. The aim of this study is, firstly, to explore 
how the financing process of CTFs works in Sweden and, secondly, to explore what potential the TAG concept may have in the Swedish market. It centres on newly started CTFs or new ventures within more established CTFs, hereafter only referred to as CTFs. The rationale for the study is that these firms and ventures constitute the basis for a growing CT sector, and that they are likely to be struggling with financial issues (IVA, 2007) and thereby may potentially gain from the TAG concept.

Two objectives are developed and pursued in order to achieve the aim. They include:

- defining of market characteristics affecting the funding process

- assessment of the potential of the TAG concept in the Swedish market.

The introduction is followed by a section critically reviewing relevant current research, resulting in the creation of a conceptual framework which outlines the CTF funding process. Thereafter, the method chosen for the study is described and the results are presented and discussed, leading to a revised conceptual framework. Finally, the conclusions are presented.

\section{Financing of CTFs}

Access to funding is one of the main factors determining the growth of new technologybased firms (NTBFs), a category which will include many CTFs (Andreassi and Rodrigues, 2006). The level of access to funding is likely to depend on at least three factors: the characteristics of the market, the entrepreneur and the investors (Table 1).

It is thereby market characteristics associated with CTFs' aversion towards external control among the entrepreneurs, and risk aversion of the financiers that contribute to what has been labelled 'a funding gap'.

\subsection{A funding gap}

Even though investments in NTBFs have risen during the last decade, investments in their early stages have decreased (Oakey, 1995, 2003). This indicates the problem of a funding gap discussed by, e.g. Giudici and Paleari (2000), Klofsten et al. (1999), Murray and Lott (1995) and Oakey (1995). Noticeably, the problem with a funding gap has been recognised but no consensus seems to have been reached regarding how to best deal with the situation.

\subsection{A conceptual framework}

A conceptual framework (Figure 1) was developed from the literature review, which schematically outlines the development and funding of CTFs. An interpretation of a market development process is captured in terms of business development, a concept development and the need for funding in various phases.

The framework distinguishes between three business development stages: research and development, expansion and commercialisation. Linked to those stages are the financing sources most commonly used, i.e. private savings and public subsidy, $\mathrm{VC}$ from business angels (BAs) and VC-funds and public equity and public debt. Surrounding the development process of the $\mathrm{CTF}$ is the market for $\mathrm{CT}$, indicating that the market and its 
characteristics influence the whole chain of development stages. The funding gap has deliberately been put in the centre of the framework since that is the focus of this study. The funding gap seems, according to the literature review, to appear in the expansion stage of the development, i.e. after the initial research but before market entry and commercialisation, i.e. in a stage were private savings and public subsidies are no longer sufficient but public equity and public debt is still far from being a realistic funding option. The literature review suggests that $\mathrm{VC}$ may constitute a suitable source of funding in the expansion stage, but that success in attracting funding also depends on the characteristics of the entrepreneur in the CTF, such as management skills necessary to develop and maintain the firm.

Table 1 Factors affecting funding opportunities for NTBFs

\begin{tabular}{|c|c|c|}
\hline Factor & Characteristics & Impact \\
\hline The market & $\begin{array}{l}\text { - The level of technology adoption can be related to a } \\
\text { perceived demand of the new technology, or to the } \\
\text { scientific advances in the society (Ruttan, 2001; } \\
\text { Schmookler, 1962, 1966) } \\
\text { - The rate of technology adoption is reliant on a certain } \\
\text { set of actions occurring in history (Arthur, 1983, } \\
\text { 1989) } \\
\text { Changing regulations play an important part in the } \\
\text { adoption of technology (Sheth and Ram, 1987) }\end{array}$ & $\begin{array}{l}\text { Increased rate of } \\
\text { technology adoption } \\
\text { facilitates the funding } \\
\text { process }\end{array}$ \\
\hline $\begin{array}{l}\text { The } \\
\text { entrepreneur }\end{array}$ & $\begin{array}{l}\text { - An entrepreneur needs a comprehensive view of the } \\
\text { business and its environment to combine internal and } \\
\text { external activities (Johannisson and Lindmark, 1996) } \\
\text { - It is vital for the entrepreneur to establish a network } \\
\text { and trustworthy relationships with external actors } \\
\text { (Johannisson and Landström, 1999; Sanner,1999) } \\
\text { - The entrepreneur needs to represent the demand side } \\
\text { in the process of financing the firm (Berggren, 2003) } \\
\text { Many entrepreneurs have an aversion towards } \\
\text { external control of the firm, and hence are reluctant to } \\
\text { take in external financing (Berggren, 2003; Berggren } \\
\text { et al., 2000; Giudici and Paleari, 2000; Massimo and } \\
\text { Grilli, 2007) }\end{array}$ & $\begin{array}{l}\text { The personal and } \\
\text { professional } \\
\text { characteristics of the } \\
\text { entrepreneur are } \\
\text { crucial in the funding } \\
\text { process }\end{array}$ \\
\hline \multirow[t]{2}{*}{ The investor } & $\begin{array}{l}\text { It is principally VC-funds and business angels (BAs) } \\
\text { that invest in NTBFs (Dahlstrand and Cetindamar, } \\
\text { 2000; Freear and Wetzel, 1990; Lindström and } \\
\text { Olofsson, 2001; Lockett et al., 2002; Oakey, 2003; } \\
\text { Osnabrugge, 2000) }\end{array}$ & $\begin{array}{l}\text { Dependence on BAs } \\
\text { and VC }\end{array}$ \\
\hline & $\begin{array}{l}\text { The size of fixed cost in relation to small investments, } \\
\text { the high level of risks associated with trying to } \\
\text { commercialise new technologies, and a general } \\
\text { reluctance from VC investors to invest in pre- } \\
\text { commercialised products (Lockett et al., 2002; Murray } \\
\text { and Lott, 1995) }\end{array}$ & $\begin{array}{l}\text { Reluctance to invest in } \\
\text { CTFs }\end{array}$ \\
\hline
\end{tabular}


Figure 1 A conceptual framework for the funding situation for CTFs
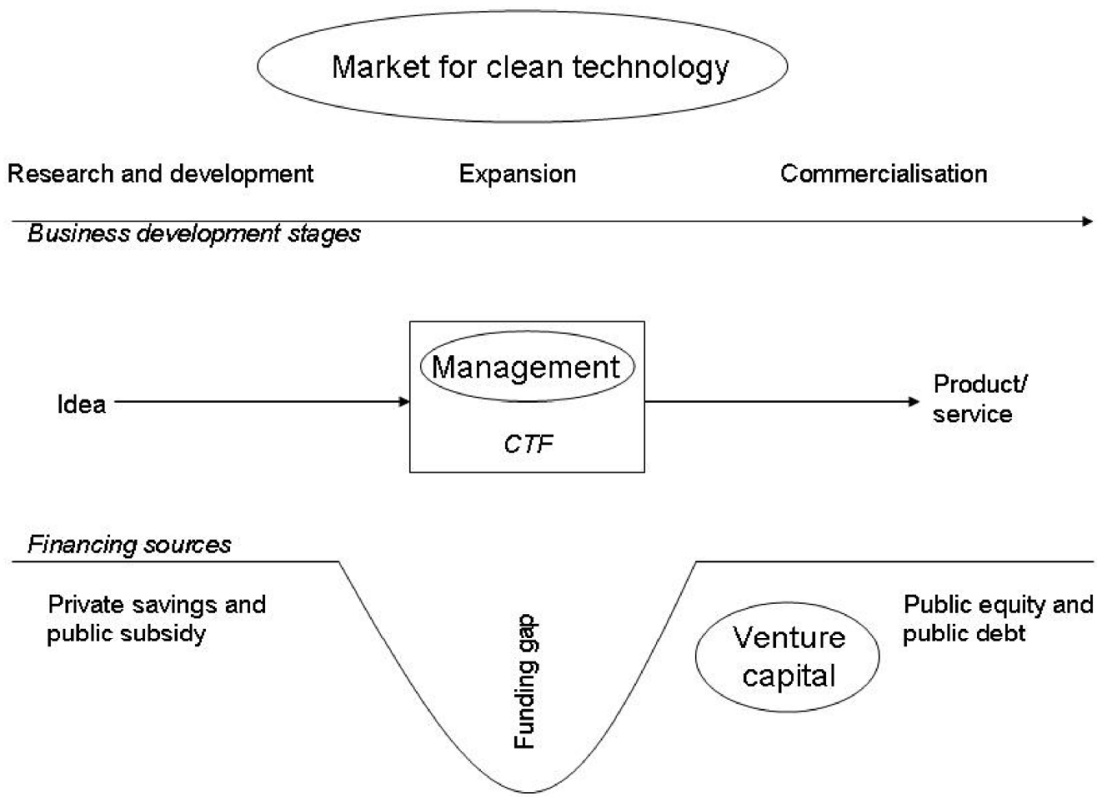

Source: Inspired by Giudici and Paleari (2000), Hsu (2004), Klofsten et al. (1999), Murray and Lott (1995) and Oakey (1995).

\section{Approach}

Methodologically, this research is based on the case study method - the study of a phenomenon in a particular context - where the case in question is the CT sector in Sweden. A flexible approach and exploratory design were chosen for this study since it focuses on a contemporary event beyond the author's control (Robson, 2002; Yin, 2003). Semi-structured interviews were applied to gather the qualitative data required to achieve the research objectives. Data gathered from the primary sources are complemented by secondary data in the form of reports focusing on contemporary issues regarding financing of CTFs.

The primary research was not intended to produce statistical inferences about a large population, but rather to generate a body of expert knowledge about key issues. The professional interviewees selected as respondents, therefore, formed a non-probability sample, using the following purposive criteria:

- knowledge of the Swedish or the UK CT market

- professional experience of CTFs in either the water or energy sector

- knowledge of the financing process for CTFs

- awareness of the TAG concept. 
About 12 professionals participated in the study, representing the three areas outlined in the conceptual framework, i.e. professionals within:

- CTFs (representing the entrepreneurs)

- $\quad \mathrm{VC}$ industry interested in CT (representing the VC-funds and BAs)

- $\quad \mathrm{CT}$ industry acting as end-users of CT (representing the market).

In addition, two professionals working with facilitating growth for the CT sector, one Swedish and one British, provided relevant input for the study. The technique of coding schemes was applied in order to analyse the data gathered, i.e. interviews and reports. In accordance with recommendations in Miles and Huberman (1994), a list of preliminary codes was developed before the field work started. This list was created on the basis of the conceptual framework and the research questions. The chosen codes proved valuable and were only slightly altered in the final analysis. From the coded data clusters were identified which were used to refine the conceptual framework and formed the base for the conclusions.

\section{Results from the research: five sources of influence}

The results have been divided into five categories drawn from the conceptual framework, and the coding scheme used in the primary research analysis:

1 the CT market

2 management of CTFs

3 VC investments in CT

4 a funding gap

5 the TAG concept.

These are presented and discussed in turn below, contributing to the objectives identified in Section 1, and to revision of the conceptual framework.

\subsection{The CT market}

More than 90,000 people are employed in Sweden in the primary and secondary environmental sector ${ }^{2}$ combined, corresponding to just over $2 \%$ of the entire Swedish workforce, and scattered over approximately 8,000 establishments ${ }^{3}$ (Brolinsson et al., 2006). The majority of the respondents do however state that the Swedish market is too small for CTFs to develop. They refer to the Swedish water sector as close to saturation forcing firms to expand internationally, supported by data showing that $40 \%$ of the turnover in the water sector comes from exports (Brolinsson et al., 2006). The water experts amongst the respondents argued that, as a result of long experience, Swedish CT knowledge in the water sector is extensive, suggesting a supply-push market. In the energy sector, on the other hand, knowledge comes from recent research rather than experience, and domestic demand for CT is higher than for water-related CT. The energy market is four times larger in monetary terms than the water market but only $3 \%$ of the CT energy turnover comes from export (Brolinsson et al., 2006), indicating a 
demand-pull situation and a strong domestic market (IVA, 2007). This picture is reflected by the interviews with Swedish investments firms who indicate that most interesting CT investments in Sweden are within the energy field. A final comment with regard to the energy sector is that it is heavily dependent on a sufficient infrastructure which to a certain extent is lacking in Sweden. This may, in accordance with the path-dependence theory (Aragón-Correra and Sharma, 2003), imply that a technology lock-in situation may hinder the growth of the CT energy market.

In addition, communication flow in the Swedish CT market has a bearing on the financing process. Johannisson (1996) states that strategic alliances, formal corporate cooperation and informal and personal networks are critical for the success of businesses, a statement supported by all the interviewees. Most respondents see their current network as sufficient, but without a formalised structure. This may support the theory of personbased trustworthiness discussed by Sanner (1999), something that is also mentioned by respondents in the study. Several respondents emphasised a situation of consultancy dependence in the CT water sector resulting in a communication flow which, to a large extent, is managed by consultants. The influence of consultants seems less extended within the energy sector, which in general appears to be more dynamic and less structured then the water sector. A majority of the respondents argue that the Swedish CT market is small enough to survey easily, but that there is a need of a better network both within specific areas of the CT field and within that field in general. None of the respondents have a negative attitude towards a more formalised network, such as the TAG concept.

Finally, the political climate is recognised as an important factor influencing the financing of CTFs, as indicated by, e.g. Steth and Ram (1987) and also respondents who argue that the success of CTFs is dependent both on regulations within the environmental field and also on subsidies facilitating the growth of the sector. The implications of political influence are recognised but are not revealed sufficiently in this study.

\subsection{Management of CTFs}

With regard to the management of CTFs, both primary and secondary data highlight a lack of entrepreneurs as a major obstacle in the funding process. The respondents and a recent Swedish governmental report (Hörte and Halila, 2007) all indicate that the CT sector in Sweden is dominated by innovators rather than entrepreneurs. This means that management teams are primarily focused on the technology development without sufficient knowledge or interest in management issues to develop or even maintain the firm. The consensus of the respondents, supported by the secondary data, is thereby that Swedish CTF managers in general do not exemplify those important entrepreneurial characteristics emphasised in the literature (Johannisson and Landström, 1999; Sanner, 1999), leading to a great risk of the funding gap problem. An example of the converse situation, which tends to support this proposition, is a CTF whose founder and chairman of the board was a respondent for this study. This company has not had any financing problems but instead attracted large amounts of $\mathrm{VC}$. This appears to be explained, at least partly, to the extensive entrepreneurial experience of management and the broad network of the respondent.

As reported by Hörte and Halila (2007) and supporting the research by Berggren (2003), managers within the CT field are highly concerned to retain control of the development of the firm, and may regard the patent as some kind of insurance for 
keeping that control. This is fully supported by the CTF respondents, who argue that they currently prefer internal financing or possibly bank loans, rather than VC, since the former will not affect the control of the firm. The opinions in this study, thereby, concur with the literature arguing that CTFs prefer self-financing (Berggren, 2003; Giudici and Paleari, 2000; Massimo and Grilli, 2007).

Returning to the importance of trustworthiness, the respondents argue that a high level of person-based trustworthiness, examined by Sanner (1999), has had major positive influence on the financing of the firm. The theory of institutional-based trustworthiness (Pater and van Gils, 2003; Sanner, 1999) is also supported in this study since the novelty of the CT sector probably is one of the main causes of the funding gap facing many CTFs.

According to Hörte and Halila (2007), the structure of the innovators' networks differs between CTFs and other technology firms. CTF managers commonly have a network centred on friends and family, while managers in other sectors emphasise the importance of including experts from different areas, e.g. fund raising or marketing specialists. The size of the respondents' networks has not been possible to measure, but differences can be distinguished. Managers of CTFs may have less contact with BAs and experience a greater lack of $\mathrm{VC}$ than managers in other fields, as argued by Hörte and Halila (2007). This is not supported by all of the respondents in this study, indicating that networks vary in size and importance between the firms.

\subsection{VC investments in $C T$}

A feature of the VC industry is its rapidly growing interest in CTFs (Deloitte, 2006). This finding is supported by a survey of the Swedish VC industry in which $70 \%$ of respondents consider $\mathrm{CT}$ to be the most interesting sector for future investments (Nutek, 2007b). The Swedish VC industry invested approximately 30 million euros in CT during 2006 (Nutek, 2007a), or $0.6 \%$ of the total amount invested that year.

When interviewed, representatives of investment firms mentioned three main types of interlinked risks associated with CT investments: political risks, technology risks and pre-commercialised risks. As a consequence, they rarely invest in firms which are dependent on local or short-term political interventions. Respondents argue that the CT sector has been more associated with political interventions than other areas, increasing the difficulty for investors. The investment firms emphasise benefits from political decisions, moving up from national to international levels, since this creates a more stable political climate in which it is easier for the investors to act. However, one respondent mentioned that politics at a higher level also may have a negative impact on the CT sector as making decisions at an international level is, generally, a slow process, poorly matching the rapid evolution of the CT market. These comments support the propositions from Sheth and Ram (1987) regarding regulation as an influence on the adoption of new technologies.

Technology and pre-commercialised risks are identified as the main causes of bias against NTBFs among investors (Lockett et al., 2002; Murray and Lott, 1995), corresponding to the challenge of creating a market for a new technology as discussed by Lindström and Olofsson (2001). According to the respondents one way of combating these risks is to obtain expert evaluations of the CTFs. The investment firms state that 
they have some technical competence within the firm, but that they often take in external experts to verify the potential of the investment. One respondent argues that BAs may be more suitable for CTFs than VC-funds. When discussing risk, this coheres well with the literature which shows that VCs carry out more comprehensive due diligence than BAs (Osnabrugge, 2000). This indicates that BAs may be less risk averse and act on premises other than risk minimisation alone, such as a sense of philanthropy as argued by respondents, and gut feeling as mentioned by Osnabrugge (2000).

Another reason for BAs' suitability as a funding source for CTFs is the size of the investment. As discussed by the majority of the respondents, VC-funds wanted to invest sums too large for most CTFs to assimilate, sums that make the fund the majority owner of the CTF. This is rarely an aim of VC-funds, thus creating a bias against CTFs. Lockett et al. (2002) state that many investments in CTFs are associated with high fixed costs in relation to the small investments, making the investors reluctant to invest. However, according to the respondents, BAs are often interested in investing smaller amounts supported by the empirical data from two of the respondents.

Timing is an additional factor in technology development for investors. VC-funds are moving towards investments in later stages in order to decrease risks (Klofsten et al., 1999; Oakey, 2003) which is supported by respondents in this study. If no other funding is made available at an early stage, a funding gap may be unavoidable. The literature indicates that BAs, generally, act at an earlier stage than VC-funds (Berger and Udell, 1998), which is supported by one of the respondents.

\subsection{A funding gap}

Despite the growing number of investments the Swedish CT sector, it still experiences a lack of VC (IVA, 2007) which indicates the existence of a funding gap. All Swedish respondents agree that this is the case in Sweden. IVA (2007) identifies four explanatory factors: lack of entrepreneurs, small size of the investments demanded, unstable political climate and problems for the VC-industry to find interesting investment objects. These factors correspond with the primary data and have been discussed above. As the primary data further indicate, three additional factors are found to increase the funding gap: namely, investors' reluctance to accept technological and pre-commercialisation risk, which is tied to the timing of investments. Finally, the IVA report (2007) highlights that the supply of early stage VC has to increase in order to maintain a successful CT industry in Sweden, and suggests that the implementation of the TAG concept could constitute a partial solution for a funding gap.

\subsection{The TAG concept}

Extensive amounts of information about the respondents' opinions of the TAG concept were collected during the interviews. This discussion covers the main topics as expressed by the respondents, i.e. not only contribution and advantages of TAG but also risks and disadvantages and the implementation process.

Respondents agree that TAG appears to be a potentially useful tool for resolving the funding gap. According to the respondents, TAG would bring two main contributions to the development of the Swedish CT market: the creation of a more structured platform which would ease communication and an increase in the number of actors in the Swedish CT sector. TAG might primarily be beneficial to small, new CTFs with few established 
contacts in the industry, but it would also bring benefits to the industry in general. The latter is explained by the increased information that would be available to the industry about alternative technologies.

Opinions expressed by the Swedish investors diverge. TAG might be a good tool to structure the communication flow and it could facilitate establishing social ties between the investors and the CTFs, which is argued to be one factor facilitating the VC-funding process (Shane and Cable, 2002). Other respondents perceive less of a need and express concern that TAG will put an additional emphasis on the technology aspects and less on the importance of good management of the firm. In addition, the reputation of the investment firm has a significant impact on the offer acceptance rate among early stage high-tech entrepreneurs (Hsu, 2004) and TAG's ability to add any value to investment firms which already possess a high reputation on the Swedish VC market may, therefore, be questioned.

The opinions in respect of geographical focus diverge extensively among the respondents. The main concern is that the Swedish market might be too small for the concept to bring any added benefit to the members, to attract investors and to have a sufficient deal flow of CTFs. This point is supported by Andreasson et al. (2008) with a major reason being that of the heterogeneity of the Swedish CT market. A market characteristics that increase the difficulty in creating a TAG for a certain technology sector.

A focus for implementation of TAG in Sweden in the energy sector as opposed to the water sector is argued in terms of high technology innovations which both attract more interest from VC investors and increase the need for technology verification. The market for energy is also more dynamic according to the respondents and supported by the secondary data. Further, Sweden is prominent with regard to research in the energy field; both in energy efficiency and renewable energy, and the large actors in the industry are perceived to be keen on supporting technology development in the area.

Key challenges with introducing a new TAG are identified as being related to appointing relevant industry partners. Several of the respondents argue that this should be relatively easy in the energy sector. The representative from the energy industry, however, argues that the energy sector might be difficult to enter since many of the actors are either large enough to be able to fund and run their own research and networks, which markedly reduces an added contribution of a TAG, or too small to have the resources to pay the fee for a TAG membership. This brings the discussion onto another topic highlighted by the respondents, namely where the funding for the TAG should come from. Respondents suggest that if a TAG is set up in the energy sector, it should be jointly funded by the industry and the Swedish government.

As the results and discussion show, the experts' opinions diverge on how to use the concept most effectively in order to address critical factors in any successful implementation. There does, however, seem to be a consensus in that TAG has the potential to positively contribute to the development of the Swedish CT market.

\subsection{A revised conceptual framework}

The TAG concept adds an additional element which was not considered in the literature review. Thereby, the framework needs to be developed (Figure 2) in order to capture the increased communication in the sector and the associated reduction of the funding gap. 
Figure 2 A revised conceptual framework for financing CT-based firms



TAG creates a network and facilitates the communication between the three sets of actors: the market (i.e. in this case the end-users); the management of the CTF and the investors. This can decrease the risk facing the investors and thereby make venture capitalists, willing to invest at an earlier stage. It will also increase the probability that the CTF may create the necessary contact to attract funding from other sources if so wished. Thus the funding gap is likely to be reduced.

Significant findings include the following: there is an abundance of innovators but a lack of entrepreneurs, which complicates the funding process; and BAs may be more suitable as a financing source for CTFs than VC-funds, because BAs generally have a lower risk aversion and higher interest in smaller investment sums. The findings can be developed into two scenarios:

1 CTFs managed by innovators with capital supplied by VC-funds

2 CTFs managed by entrepreneurs with capital supplied by BAs.

The first scenario coheres well with the picture presented in the initial version of the conceptual framework (Figure 1). In the second scenario, TAG or BA may supply capital (Figure 2). It seems likely that the management characteristics of an entrepreneur (e.g. an extensive network and an interest in involving external investors), and the interest expressed by BAs in investing at an earlier stage, will both affect the process in the same direction, i.e. closing the funding gap. According to the primary data, and supported by the secondary data, the first scenario does seem to occur more often than the second, implying a need for a concept like TAG.

The question whether the Swedish water or energy market is more suitable for a TAG solution does not lend itself to an easy answer. Due to the multitude of factors it is very difficult to determine whether or not these different markets correspond with either of the 
frameworks above. A diversified market structure (Andreasson et al., 2008) may create difficulties in obtaining technical expertise independent of the firm which can, on behalf of the investor, assess the technical potential of the product, a situation which further emphasises the need for TAG. One example of this complexity is the higher technical level associated with the energy sector. This will probably lead to a greater potential for good financial returns, attracting investors and thereby tending to reduce the funding gap, but it may also increase the technology risk making investors more reluctant to invest and conversely tending to increase the funding gap. Hence a fuller understanding of the effect of this array of factors on the process of funding will need further investigation.

\section{Conclusions and recommendations for further studies}

This study has identified that the main obstacles and challenges, described above, both for CTFs to attract funding and for investors to find suitable investment objects in the CT sector are interlinked. Important factors highlighted in the literature are fully supported by the research results. The research also indicated an abundance of innovators and a lack of entrepreneurs as one of the main causes of the funding gap identified in the literature. Further, BAs might be the most appropriate source of funding for CTFs since VC-funds, in general, seem to perceive CTFs as too risky to invest in and the sums appropriate for investment as too small. According to both the literature and the data gathered in this study, the size of the market, the communication platforms and the political climate are the factors affecting the funding process.

The nature of the funding gap in the Swedish CT sector revealed by both primary and secondary data is represented in a revised conceptual framework (Figure 2). Since one of the main aims of the TAG concept is to facilitate the funding process of CTFs, it is likely that there is a potential for the concept to be applied in Sweden, especially within the energy sector. It is, however, important to design the fee system with caution, and to highlight the importance of trust (which is closely tied to the quality of the TAG performance), and of selecting TAG members with expertise and integrity. Each of the TAG members contributes to balancing access to information. Therefore, a recruitment plan for TAG members needs to take into account personal values, previous experience and representation of various interests in order to ensure quality assurance in TAG output. The challenge of finding individuals with expertise but no dependencies emphasises the need for professional codes of conduct (Pater and van Gils, 2003) even if these codes by no means provide any guarantee for ethical behaviour. A preliminary assessment indicate a good potential for the TAG concept in the Swedish CT market, mainly due to the existing funding gap, but that several challenges still remain to be solved.

As indicated in the study, investments in the CT sector are increasing rapidly as a part of ambitions to develop more sustainable technologies. As a result, the TAG concept is spreading to other geographical markets than those of the UK and Sweden and also to other CT sectors. There are numerous reports covering CT investments aiming for more sustainable solutions in various fields (i.e. Andreasson et al., 2008; Berggren and Dagh, 2008; Danell et al., 2008), and the TAG concept in this wider perspective has not been investigated here due to resource limits, suggesting good opportunities for further studies. It would, for example, be interesting to extend the research to other CT sectors and to make a deeper analysis of the UK water market and an evaluation of TAG in that context. 
A more thorough investigation of concepts with the same aim as TAG would also be a helpful step in promoting the development of markets for more sustainable technologies.

The current problem with a funding gap in the CT sector will probably remain for some time, creating opportunities to apply the TAG concept. That opportunity is likely to diminish over time, however, as a result of market growth, recognition and knowledge of the $\mathrm{CT}$ sector, leading to a situation where $\mathrm{CT}$ is associated less with perceived risks.

\section{References}

Andreassi, T. and Rodrigues, E. (2006) 'The funding of new technology-based firms in Brazil', Int. J. Entrepreneurship and Innovation Management, Vol. 6, Nos. 4-5, pp.369-379.

Andreasson, U., Flack, M., Forsberg, T., Johsson, S., Lindberg, M., Vinger, E. and Widegren, K. (2008) Svensk Miljöteknik. En Kartläggning av Aktörer, Marknader och Konkurrenter. Östersund: Institutet för Tillväxtpolitiska Studier (ISSN 1652-0483).

Aragón-Correra, A. and Sharma, S. (2003) 'A contingent resource-based vie of proactive environmental strategy', Academy of Management, Vol. 28, No. 1, pp.71-88.

Arthur, B. (1989) 'Competing technologies, increasing returns and lock-in by historically small events', The Economic Journal, Vol. 99, pp.116-131.

Arthur, W.B. (1983) 'Computing technologies and historical small events: the dynamics of choice under increasing returns', International Institute for Applied System Analysis Paper WP Laxenburg Austria, pp.83-90.

Berger, A.N. and Udell, G.F.(1998) 'The economics of small business finance: the roles of private equity and debt markets in the financial growth cycle', Journal of Banking and Finance, Vol. 22, No. 6, pp.613-673.

Berggren, B. (2003) 'Tillväxt och lönsamhet i småföretag - finansiärers bidrag sett ur ett företags perspektiv', in H. Landström (Ed.), Småföretaget och Kapitalet, Kristianstad: SNS Förlag, pp.45-66.

Berggren, B., Olofsson, C. and Silver, L. (2000) 'Control aversion and the search for external financing in Swedish SMEs', Small Business Economics, Vol. 15, No. 3, pp.233-242.

Berggren, T. and Dagh, L. (2008) Riskkapitalbolagens Aktiviteter och Finansiering i Tidiga Skeden Kvartal 1 2008. Stockholm: SVCA Nutek Innovationsbron.

Brolinsson, H., Cederlund, M. and Eberhardson, M. (2006) Environmental Goods and Services Sector in Sweden 2002-2005. Örebro: Statistiska Centralbyrån.

Dahlstrand, Å.L. and Cetindamar, D. (2000) 'The dynamics of innovation financing in Sweden', Venture Capital, Vol. 2, No. 3, pp.203-221.

Danell, T., Gadd, H., Lighander, J. and Bager-Sjögren, L. (2008) Den Svenska Innovationspolitikens Framväxt, Organisering och Utbärderbarhet. Östersund: Institutet för tillväxtpolitiska studier ITPS.

Deloitte (2006) Global Trends in Venture Capital 2006 Survey. Deloitte Touche Tohamtsu. Available at: http:/www.deloitte.com/assets/Dcom-Montenegro/Local\%20Assets/Documents/ me_global_venture_capital_survey_281106.pdf, Accessed on 1 February 2011.

EVCA (2006) 2006 EVCA Private Equity, p.4.

Freear, J. and Wetzel, W. (1990) 'Who bankrolls high-tech entrepreneurs?', Journal of Business Venturing, Vol. 5, No. 2, pp.77-90.

Giudici, G. and Paleari, S. (2000) 'The provision of finance to innovation: a survey conducted among Italian technology-based small firms', Small Business Economics, Vol. 14, No. 1, pp.37-55.

Hsu, D. (2004) 'What do entrepreneurs pay for venture capital affiliation?', The Journal of Finance, Vol. 59, No. 4, pp.1805-1844. 
Hörte, SÅ. and Halila, F. (2007) Är Miljöinnovatörer Mindre Framgångsrika än Andra Innovatörer? R 2007:05. Stockholm: NUTEK.

IVA (Kungliga ingenjörsvetenskapsakademien) (2007) Miljöarbetets nya Arena. Panel: Miljödriven Strukturomvandling. Stockholm: IVA.

Johannisson, B. (1996) 'Personliga nätverk som kraftkälla i företagande', in B. Johannisson and L. Lindmark (Eds.), Företag, Företagare, Företagsamhet, Lund: Studentlitteratur, pp.122-150.

Johannisson, B. and Lindmark, L. (1996) 'Det mångfasetterade småföretagandet', in B. Johannisson and L. Lindmark (Eds.), Företag, Företagare, Företagsamhet, Lund: Studentlitteratur, pp.11-33.

Johannisson, B. and Landström, H. (Eds.) (1999) Images of Entrepreneurship and Small Businesses. Lund: Studentlitteratur.

Klofsten, M., Jonsson, M. and Jorgen, S. (1999) 'Supporting the pre-commercialization stages of technology-based firms: the effects of small-scale venture capital', Venture capital, Vol. 1, No. 1, pp.83-93.

Lindström, G. and Olofsson, C. (2001) 'Early stage financing of NTBFs: an analysis of contributions from support actors', Venture Capital, Vol. 3, No. 2, pp.151-168.

Lockett, A., Murray, G. and Wright, M. (2002) 'Do UK venture capitalists still have a bias against investment in new technology firms', Research Policy, Vol. 31, No. 6, pp.1009-1030.

Massimo, C. and Grilli, L. (2007) 'Funding gaps? Access to bank loans by high-tech start-ups', Small Business Economics, Vol. 29, Nos. 1 and 2, pp.25-47.

Miles, M. and Huberman, A. (1994) Qualitative Data Analysis: An Expanded Sourcebook (2nd ed.). London: Sage Publication.

Murray, G. and Lott, J. (1995) 'Have UK venture capitalists a bias against investment in new technology-based firms?', Research Policy, Vol. 24, No. 2, pp.283-299.

Nutek (2007a) Riskkapitalbolagens Aktiviteter och Annan Finansiering i Tidiga Skeden R2007:07. Stockholm: Nutek.

Nutek (2007b) Riskkapitalbolagens Aktiviteter och Finansiering i Tidiga Skeden Första kvartalet R2007:14. Stockholm: Nutek.

Oakey, R.P. (1995) High Technology New Firms: Variables Barriers to Growth. London: Paul Chapman Publishing.

Oakey, R.P. (2003) 'Funding innovation and growth in UK new technology-based firms: some observations on contributions from the public and private sectors', Venture Capital, Vol. 5, No. 2, pp.161-179.

Osnabrugge, M.V. (2000) 'A comparison of business angel and venture capitalist investment procedures: an agency theory-based analysis', Venture Capital, Vol. 2, No. 2, pp.91-109.

Pater, A. and van Gils, A. (2003) 'Stimulating ethical decision-making in a business context: effects of ethical and professional codes', European Management Journal, Vol. 21, No. 6, pp.762-772.

Robson, C. (2002) Real World Research (2nd ed.). Oxford: Blackwell Publishing.

Ruttan, V.W. (2001) Technology, Growth, and Development. An Induced Innovation Perspective. Oxford: Oxford University Press.

Sanner, L. (1999) 'Trust between entrepreneurs in new business ventures and external actors', in B. Johannisson and H. Landström (Eds.), Images of Entrepreneurship and Small Businesses. Lund: Studentlitteratur, pp.58-81.

Schmookler, J. (1962) 'Changes in industry and in the state of knowledge as determinants of industrial invention', in R. Nelson (Ed.), The Rate and Direction of Inventive Activity: Economic and Social Factor. Princeton NJ: Princeton University Press, pp.195-232.

Schmookler, J. (1966) Invention and Economic Growth. Cambridge, MA: Harvard University Press. 
Shane, S. and Cable, D. (2002) 'Network ties, reputation, and the financing of new ventures', Management Science, Vol. 48, No. 3, pp.364-381.

Sheth, J.N. and Ram, S. (1987) Bringing Innovation to Market. How to Break Corporate and Customer Barriers. New York: Wiley and Sons.

Yin, R. (2003) Case Study Research. Design and Methods (3rd ed.), London: Sage Publications.

\section{Notes}

${ }^{1}$ According to the European private equity and venture capital association (EVCA) clean technologies are defined as:

“...a diverse range of products, services, and processes that are inherently designed to provide superior performance at lower costs, greatly reduce or eliminate environmental impacts and, in doing so, improve the quality of life. Clean technologies span many industries such as agriculture, energy, manufacturing, transport and water." (EVCA, 2006, p.4)

${ }^{2}$ The primary environmental sector includes establishments with more than $50 \%$ environmental production while the secondary environmental sector includes establishments with less than $50 \%$ environmental production. This study focuses on the total figures for the environmental sector in order to give an complete overview as possible.

${ }^{3}$ Statistics Sweden's database includes establishments instead of companies in order to reflect the market more correctly. A company and an establishment are usually the same thing but a company may consist of several establishments, e.g. in different locations. 